\title{
Rhizosphere-induced heavy metal(loid) transformation in relation to bioavailability and remediation
}

\author{
B. Seshadri ${ }^{1,2^{*}}$, N.S. Bolan ${ }^{1,2}$ and R. Naidu ${ }^{1,2}$ \\ ${ }^{1}$ Centre for Environmental Risk Assessment and Remediation, University of South Australia, Mawson Lakes, \\ Australia ${ }^{2}$ Cooperative Research Centre for Contamination Assessment and Remediation of the Environment, \\ Adelaide, Australia*Corresponding author: Balaji.Seshadri@unisa.edu.au
}

\begin{abstract}
Soil is the sink and source of heavy metals (both geogenic and anthropogenic) and plants are the ecosystem regulators, balancing the chemistry of life on earth. However, roots are the only connection between soil and plants, which are the real engineers of ecosystem dynamics responsible for environmental balance and stability. The plant-soil interface termed as 'rhizosphere' is a typical zone of soil where the physical, chemical and biological characteristics are different from bulk soil (outside the rhizosphere region). This is mainly controlled by physiological response from plants to the environmental changes through exudation of chemicals from root region and the cascade of chemical (changes in $\mathrm{pH}$ and redox potential, release of anions and nutrient transformation) and biological (microbial association) events that follow. The other adaptive mechanisms include root length and area as affected by temperature, moisture and nutrient content of the soil. In the recent years, advanced technologies have lead to significant findings at the micro-level in rhizosphere research, targeting the role of root-soil interface towards nutrient availability and agricultural productivity. However, with increasing human activities (including agriculture), undesirable quantites of heavy metals are being added to the environment thereby resulting in soil contamination. This review will discuss in detail on the processes involved in the (im)mobilisation of heavy metals in and around the root region as affected by chemical ( $\mathrm{pH}$ and root exudates) and biological (microorganisms) components.
\end{abstract}

Keywords: Metal(loid)s, bioavailability, phytoremediation, rhizosphere, transformation, root exudates

\section{Introduction}

'Heavy metal(loid)s' generally includes elements (both metals and metalloids) with an atomic density greater than $6 \mathrm{~g} / \mathrm{cm}^{3}$ [with the exception of arsenic (As), boron (B), and selenium (Se)]. This group includes both biologically essential [e.g., cobalt $(\mathrm{Co})$, copper $(\mathrm{Cu})$, chromium $(\mathrm{Cr})$, manganese $(\mathrm{Mn})$, and zinc $(\mathrm{Zn})$ ], and non-essential [e.g., cadmium $(\mathrm{Cd})$, lead $(\mathrm{Pb})$, and mercury $(\mathrm{Hg})]$ elements. The essential elements (for plant, animal, or human nutrition) are required in low concentrations and hence are also known as 'trace elements' or 'micro nutrients'. The non-essential elements 
are phytotoxic and/or zootoxic and are widely known as 'toxic elements'. Both groups are toxic to plants, animals and/or humans at extremely high concentrations. Build-up of these soil-borne elements in the human food chain depends on the amount and source of heavy metal(loid) input, soil properties, rate and magnitude of plant uptake and influenced by their bioavailability, and the extent of absorption by animals (Adriano, 2001).

With increasing demand for safe disposal of wastes generated from agricultural and industrial activities, soil is not only considered as a source of nutrients for plant growth, but also used as a sink for the removal of contaminants from these waste materials. As land treatment becomes an important waste management practice, soil is increasingly being seen as a major source of heavy metal(loid)s reaching the food chain, mainly through plant uptake and animal transfer. Such waste disposals have led to significant build up of a wide range of metal(loid)s in soils, such as arsenic (As), cadmium (Cd), chromium $(\mathrm{Cr})$, copper $(\mathrm{Cu})$, mercury $(\mathrm{Hg})$, lead $(\mathrm{Pb})$, selenium $(\mathrm{Se})$, and zinc (Zn). Since metal(loid)s do not undergo chemical degradation, they persist for a long time in soil, posing threat to soil and environmental health (Adriano et al., 2004).

There are a number of remediation strategies including physical (e.g. replacement of contaminated soil with clean soil), chemical (e.g. immobilisation using lime and phosphate compounds) and biological (bioremediation using microorganisms and/or plants) methods. The first two approaches are expensive and hence plant-aided remediation termed as 'phytoremediation' is increasingly being researched for restoration of heavy metal(loid) contaminated sites (Robinson et al., 2006). In this approach, plants are generally used to extract the heavy metal(loid) $\mathrm{s}$ and the process is termed as phytoextraction. In some cases where the phytoextraction is not viable due to bioavailaibility factors, in situ immobilization (e.g. phytostabilisation) is also considered as a phytoremediation strategy.

Any phytoremediation process starts at the soilplant interface or the root zone region termed as 'rhizosphere' and hence the process of heavy metal(loid)s transformation mainly occurs in this region. With increasing demand for safe disposal of wastes generated from agricultural and industrial activities, rhizosphere soil is not only considered as a source of nutrients for plant growth, but also used as a sink for the removal of contaminants from these waste materials. The complexity of the rhizosphere region, the sources and dynamics of heavy metal(loid) $\mathrm{s}$ in soil and the role rhizosphere in heavy metal(loid) transformation will be presented in this review, with focus on bioavailability of heavy metal(loid)s and remediation of the contaminated soil.

\section{Sources of heavy metals}

Soil is the major sink for contaminant chemicals including excessive nutrients and undesirable quantities of heavy metals, which also makes it as a major source of these materials. Similarly, sediments in water are considered as the ultimate sink for these chemicals. Heavy metals reach the soil environment through both pedogenic (or geogenic) and anthropogenic processes. Arsenic (As) is the best example of a heavy metal(loid) released by natural processes. For example, in countries like India, China and Bangladesh, As release from ground water is a serious issues which were found to be transported from the sedimentarty rocks of Himalayan origin over several centuries (Mahimairaja et al., 2005; Yu et al., 2007; Armienta et al., 1997; Del Razo et al., 1990). Majority of the naturally occurring sources are not readily available to plant uptake compared to the ones that are released from human activities (Lamb et al., 2009; Naidu and Bolan, 2008; Naidu et al., 1996). Most anthropogenic 
activities, such as industrial processes, manufacturing and the disposal of domestic and industrial waste materials release heavy metals which are highly available for plant uptake (Table 1; Adriano 2001; McLaughlin et al. 1996). Atmospheric pollution from $\mathrm{Pb}$-based petrol is a major issue in many developing countries where there is no constraint on the usage of leaded gasoline. While sewage sludge is the major source of metal inputs in Europe and North America. Phosphorus (P) fertilizers are considered to be the major source of heavy metal(loid) input, especially Cd, in Australia and New Zealand.

The main source of $\mathrm{P}$ for agricultural usage is phosphate rocks (PRs), which also contains considerable quantities of heavy metal(loid)s (Table 2). Addition of P compounds to soils not only helps to overcome the deficiency of some of the essential trace elements, such as Mo, but also introduces toxic metals such as $\mathrm{Cd}$. In the case of $\mathrm{Mo}, \mathrm{P}$ addition results in surface complexation reactions along with soil components including aluminium oxides, thereby reducing the adsorption of Mo (Goldberg, 2010). Wu et al. (2001) studied Mo adsorption in soil in the presence of equimolar phosphate concentration and found that phosphate decreased Mo adsorption in soil. Most agricultural soils fertilised with PRs for over several years are prone to $\mathrm{Cd}$ toxicity thereby affecting the quality of food crops and consequently affecting the overall food chain (Bao et al., 2011). It is important to stress that PR deposits vary in their $\mathrm{Cd}$ content, leading to the variation in $\mathrm{Cd}$ contents of manufactured $\mathrm{P}$ fertilizers. With rich source of $\mathrm{Cd}$ from $\mathrm{P}$ fertilizers, large quantities of $\mathrm{Cu}$ are used in agriculture, horticulture and animal industries as formulations of $\mathrm{Cu}$ containing fungicides, such as copper oxichloride and 'Bordeaux' mixture, and as a growth promoter in piggery and poultry units (Adriano, 2001; Bao et al., 2011). Copper containing fungicides are quite effective in controlling many fungal diseases and are also accepted in 'organic' farming (Komárek et al., 2010). Even with increasing interest in 'organic' farming, the widespread use of $\mathrm{Cu}$ fungicides is likely to continue in vineyards and citrus orchards. Accumulation of $\mathrm{Cu}$ in agricultural soils resulting from continuous use of $\mathrm{Cu}$ fungicides and sludge application has been reported in many countries. One of the major consequences of excessive accumulation of $\mathrm{Cu}$ in soils is its toxicity to plants and microbial communities.

Another prominent heavy metal is Cr from tannery and timber treatment effluents. Approximately, 6400 and 1600 tons of tannery and timber treatment effluents, respectively, are generated annually in New Zealand, and these effluents are considered to be the major sources of $\mathrm{Cr}$ contamination into aquatic and terrestrial environments. Chromium is used as $\mathrm{Cr}$ (III) in the tannery industry and as $\mathrm{Cr}(\mathrm{VI})$ in the timber treatment industry. $\mathrm{Cr}(\mathrm{VI})$ is highly toxic and carcinogenic even when present in very low concentrations in water. Large scale use of tannelised timber (treated with CCA) as fence post and in vineyards can also result in the release of $\mathrm{Cu}, \mathrm{Cr}$ and As to soil environment.

\section{Transformation of heavy metal(loid)s in soils}

The general mechanisms involved in the transformation of metal(loid) ions in the soil lead to retention (mediated by sorption, precipitation, and complexation reactions) or loss (plant uptake, leaching, and volatilization) of heavy metal(loid)s (Figure 1). Although most metal(loid) $\mathrm{s}$ do not undergo volatilization related losses, some metal(loid)s such as $\mathrm{As}, \mathrm{Hg}$, and Se tend to form gaseous compounds (Mahimairaja et al., 2005; Bolan et al., 2013). The lower the metal(loid) solution concentration and the more sites available for sorption, the more likely that sorption/desorption processes will determine the soil solution concentration. However, the fate of metal(loid)s in the soil environment is dependent on both soil properties and environmental factors. 
Table 1. Sources of heavy metals in soils and their expected ionic species in soil solution

\begin{tabular}{|c|c|c|c|c|}
\hline Metal & $\begin{array}{l}\text { Density } \\
\left(\mathrm{g} / \mathrm{cm}^{3}\right)\end{array}$ & Ionic species in soil solution & Contaminant sources & Toxicity $^{a}$ \\
\hline Arsenic (As) & 5.73 & $\begin{array}{l}\mathrm{As}(\mathrm{III}): \mathrm{As}(\mathrm{OH})_{3}, \mathrm{AsO}_{3}{ }^{3-} ; \mathrm{As}(\mathrm{V}): \\
\mathrm{H}_{2} \mathrm{As}_{4}{ }^{-}, \mathrm{HAsO}_{4}{ }^{2-}\end{array}$ & $\begin{array}{l}\text { Timber treatment, paints, pesticides, } \\
\text { geothermal }\end{array}$ & $\begin{array}{l}\text { Toxic to plants, humans and } \\
\text { animals }\end{array}$ \\
\hline Cadmium $(\mathrm{Cd})$ & 8.64 & $\mathrm{Cd}^{2+}, \mathrm{CdOH}^{+}, \mathrm{CdCl}^{-}, \mathrm{CdHCO}_{3}^{+}$, & Electroplating, batteries, fertilizers & $\begin{array}{l}\text { Toxic to plants, humans and } \\
\text { animals }\end{array}$ \\
\hline Chromium $(\mathrm{Cr})$ & 7.81 & $\begin{array}{c}\mathrm{Cr}(\mathrm{III}): \mathrm{Cr}^{3+}, \mathrm{CrO}_{2}^{-}, \mathrm{CrOH}^{2+}, \\
\mathrm{Cr}(\mathrm{OH})_{4}^{-} ; \mathrm{Cr}(\mathrm{VI}): \mathrm{Cr}_{2} \mathrm{O}_{7}^{2-},\end{array}$ & $\begin{array}{l}\text { Timber treatment, leather tanning, } \\
\text { pesticides, dyes }\end{array}$ & $\begin{array}{l}\mathrm{Cr}(\mathrm{VI}) \text { toxic to plants, } \\
\text { humans and animals }\end{array}$ \\
\hline Copper $(\mathrm{Cu})$ & 8.96 & $\mathrm{Cu}^{2+}(\mathrm{II}), \mathrm{Cu}^{2+}$ (III) & $\begin{array}{l}\text { Fungicides, electrical, paints, } \\
\text { pigments, Timber treatment, } \\
\text { fertilizers, mine tailings }\end{array}$ & $\begin{array}{l}\text { Toxic to plants, humans and } \\
\text { animals }\end{array}$ \\
\hline Lead $(\mathrm{Pb})$ & 11.35 & 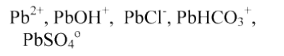 & $\begin{array}{l}\text { Batteries, metal products, } \\
\text { preservatives, petrol additives }\end{array}$ & $\begin{array}{l}\text { Toxic to plants, human and } \\
\text { animal }\end{array}$ \\
\hline Manganese (Mn) & 7.21 & $\mathrm{Mn}^{2+}, \mathrm{MnOH}^{+}, \mathrm{MnCl}^{-}, \mathrm{MnCO}_{3}^{\circ}$ & Fertilizer & Toxic to plants \\
\hline Mercury $(\mathrm{Hg})$ & 13.55 & $\begin{array}{l}\mathrm{Hg}^{2+}, \mathrm{HgOH}^{+}, \mathrm{HgCl}_{2}{ }^{\circ}, \mathrm{CH}_{3} \mathrm{Hg}^{+}, \\
\mathrm{Hg}(\mathrm{OH})_{2}{ }^{\circ}\end{array}$ & Instruments, fumigants, geothermal & Toxic to humans and animals \\
\hline Molybdenum (Mo) & 10.2 & $\mathrm{MoO}_{4}{ }^{2-}, \mathrm{HMoO}_{4}^{-}, \mathrm{H}_{2} \mathrm{MoO}_{4}{ }^{\circ}$ & Fertilizer & Toxic to animals \\
\hline Nickel (Ni) & 8.90 & $\mathrm{Ni}^{2+}, \mathrm{NiSO}_{4}{ }^{\circ}, \mathrm{NiHCO}_{3}^{+} \mathrm{NiCO}_{3}{ }^{\circ}$ & Alloys, batteries, mine tailings & Toxic to plants and animals \\
\hline Zinc $(\mathrm{Zn})$ & 7.13 & 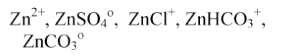 & $\begin{array}{l}\text { Galvanizing, dyes, paints, timber } \\
\text { treatment, fertilizers, mine tailings }\end{array}$ & Toxic to plants \\
\hline
\end{tabular}

${ }^{a}$ most likely to observe at elevated concentrations in soils and water. ${ }^{b}$ while $\mathrm{Cr}(\mathrm{VI})$ is very mobile and highly toxic, $\mathrm{Cr}$ (III) is essential in animal and human nutrition and generally immobile in the environment

Table 2. Metal concentration in phosphate compounds from various phosphate rock sources (Adriano 2001; McLaughlin et al. 1996; Syers et al. 1986).

\begin{tabular}{llllllllll}
\hline $\begin{array}{l}\text { Phosphate } \\
\text { compound }^{a}\end{array}$ & \multicolumn{7}{c}{ Concentration $(\mathbf{m g} / \mathbf{k g})$} & & \\
\hline & As & Cd & Co & Cu & Zn & Mn & Ni & Pb & Hg \\
GPR & 4 & 38 & 3 & 15 & 393 & 7 & & & \\
NFPR & 7 & 3 & 5 & 4 & 57 & 212 & & & \\
JPR & 12 & 4 & $<1$ & 8 & 235 & 5 & & & \\
NCPR & 23 & 48 & 2 & 9 & 400 & 7 & $9-51$ & $<1-$ & $0.4-$ \\
& & & & & & & 51 & 2.1 \\
SPR & 5 & 11 & 3 & 6 & 178 & 91 & & & \\
MPR & 3 & 8 & 6 & 4 & 90 & 151 & & & \\
NIPR & 3 & 100 & 6 & 8 & 1010 & 122 & & & \\
APR & 7 & 12 & 4 & 12 & 560 & 2 & & & \\
MIPR & 2 & 10 & $<1$ & 6 & 220 & 2 & & & \\
CRP & & 2 & 4 & 5 & 95 & 100 & & & \\
IRP & & & 109 & 32 & 187 & 975 & & 962 & \\
SSP & & & 77 & 15 & 165 & 890 & 488 & \\
TSP & & & 47 & 49 & 418 & 75 & 238 & \\
DAP & & & 16 & 7.2 & 112 & 307 & 195 & \\
\hline
\end{tabular}

aPhosphate rocks: GPR - Gafsa phosphate rock, NFPR - North Florida phosphate rock, JPR - Jordan phosphate rock, NCPR North Carolina phosphate rock, SPR -Sechura phosphate rock, MPR- Mexican phosphate rock, NIPR - Nauru Island phosphate rock, ARP - Arad phosphate rock, MIPR - Makatea Island phosphate rock, CRP, Chatham Rise phosphorite, IPR - Indian phosphate rock; Phosphate fertilizers: SSP - Single super phosphate, TSP - Triple superphosphate, DAP - Diammonium phosphate. 


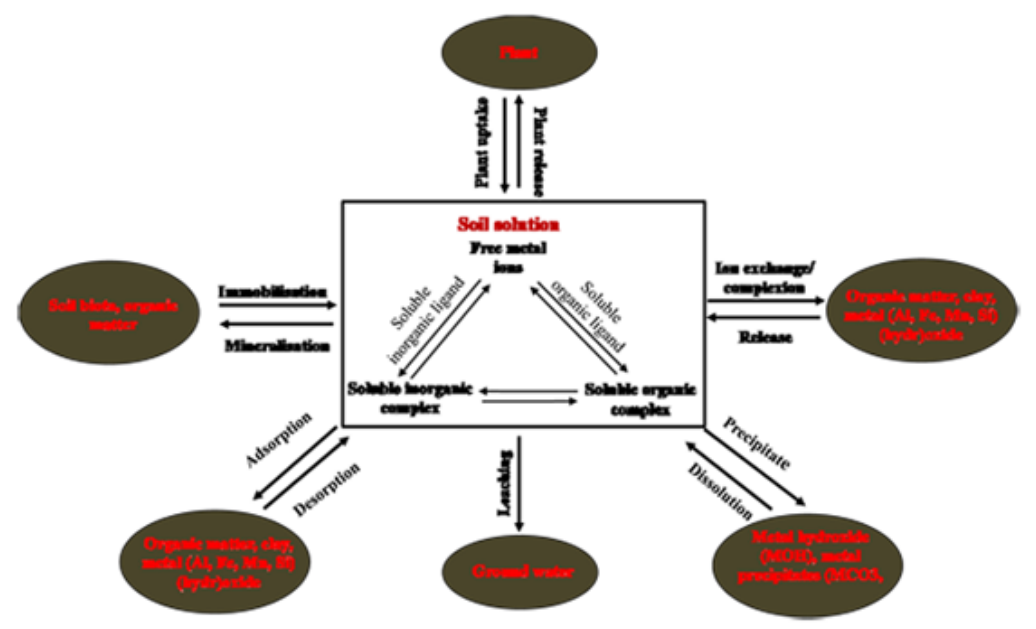

Figure 1. Possible reactions involved in physical, chemical and biological transformation of metal(loid)s in soil

\subsection{Sorption/desorption process}

Electrostatic attraction and/or specific bond formation are the two mechanisms behind the rentention of charged solute species (ions) to the charged soil surface, which can be broadly grouped into specific and non-specific retention (Bolan et al., 1999; Sparks, 2003; Li et al., 2006). The former involves chemical bond formation between the ions in the solution and those in the soil surface, whereas in non-specific adsorption, the charge on the ions balances the charge on the soil particles through electrostatic attraction (Li et al., 2006; Sposito, 1984; Zenteno et al., 2013).

A dynamic equilibrium occurs between metal(loid) $\mathrm{s}$ in solution and soil's solid phase, which is controlled both by soil properties and soil solution composition. While soil $\mathrm{pH}$ is the main factor influencing the sorption processes of the metal(loid)s, the nature of inorganic $\left(\mathrm{HPO}_{4}^{2-}, \mathrm{NO}_{3}^{-}, \mathrm{Cl}\right.$, and $\left.\mathrm{SO}_{4}^{2-}\right)$ and organic (citrate, oxalate, fulvic, dissolved organic carbon) ligand ions present in soil affects the concentration of metal(loid)s in soil solution (Bolan et al., 2003; Harter and Naidu, 1995). The inorganic anions can either form ion pair complexes with metal(loid)s thereby reducing their sorption (Hong et al., 2010) or they can increase the negative charge on soil particles, thereby increasing the sorption of cationic metal(loid)s (Naidu et al., 1994).

Most of the heavy metal(loid) ions in soil solution decreases with increase in $\mathrm{pH}$ because of increase in $\mathrm{pH}$ dependent surface charge on oxides of $\mathrm{Fe}, \mathrm{Al}$ and $\mathrm{Mn}$; chelation by organic matter, or precipitation as metal(loid) hydroxides (Mouta et al., 2008; Stahl and James, 1991). Generally, an increase in soil $\mathrm{pH}$ increases the removal of both CEC a the total amount of heavy metal(loid)s from the soil (Shuman, 1986; Violante et al., 2010). Complexation reactions between metal(loid)s and inorganic/organic ions could also contribute to metal(loid) retention, where the organic component of soil constituents possessing ligands forms chelates with meta(loid)s (Bolan et al., 2011; Harter and Naidu, 1995). With increasing $\mathrm{pH}$, the carboxyl, phenolic, alcoholic, and carbonyl functional groups in soil organic matter dissociate, thereby increasing the affinity of ligand ions for metal(loid) cations. The extent of metal(loid)organic complex formation, however, varies with a number of factors including temperature and concentration. All these interactions are controlled by solution $\mathrm{pH}$ and ionic strength, the nature of the metal(loid) species, dominant cation, and inorganic and organic ligands present in the soil solution. 


\subsection{Precipitation/dissolution}

Soils with high $\mathrm{pH}$ and high concentration of heavy metal(loid) ions have more chances of precipitation as a dominant process of metal(loid) immobilization, where the presence of anions such as $\mathrm{SO}_{4}^{2-}, \mathrm{CO}_{3}^{2-}, \mathrm{OH}^{-}$, and $\mathrm{HPO}_{4}^{2-}$ facilitates the process (Naidu et al., 1997; Hong et al., 2007; Ok et al., 2010). For example, McGowen et al. (2001) observed a decrease in the leaching of $\mathrm{Cd}$, $\mathrm{Pb}$, and $\mathrm{Zn}$ using activity-ratio diagrams indicating $\mathrm{P}$ (diammonium phosphate) induced decrease in solution metal(loid) concentrations, as facilitated by the formation of metal(loid)-P precipitates. Similarly, an increase in $\mathrm{pH}$ as a result of liming typically enhanced the retention of metals (Adriano, 2001; Bolan and Thiagarajan, 2001).

In the presence of iron oxyhydroxides, co-precipitation of metal(loid)s has also been reported at low $\mathrm{pH}$ and often such interactions lead to significant changes in the surface chemical properties of the substrate. For example, $\mathrm{Lu}$ et al. (2011) confirmed that co-precipitation of $\mathrm{Pb}^{2+}$ with ferric oxyhydroxides occurred at $\sim \mathrm{pH} 4$ and is more efficient than adsorption in removing $\mathrm{Pb}^{2+}$ from aqueous solutions at similar sorbate/sorbent ratios and $\mathrm{pH}$. Sorption of arsenate $(\mathrm{As}(\mathrm{V}))$ onto ferrihydrite; and $\mathrm{Ni}^{2+}$ and $\mathrm{Cr}^{3+}$ onto hydrous iron oxides showed that co-precipitation was more efficient process than sorption for metal(loid) removal from aqueous solutions. In another instance, Violante et al. (2007) noticed that $\mathrm{As}(\mathrm{V})$ was desorbed by $\mathrm{P}$ from a ferrihydrite on which $\mathrm{As}(\mathrm{V})$ was added than from a Fe- $\mathrm{As}(\mathrm{V})$ co-precipitate.

\subsection{Oxidation/reduction}

Metal(loid)s such as $\mathrm{As}, \mathrm{Cr}, \mathrm{Hg}$, and $\mathrm{Se}$, are most commonly subjected to microbial oxidation/reduction reactions, thereby affecting their speciation and mobility (Table 3). Redox reactions influence the speciation and mobility of metal(loid)s. For example, metals generally are less soluble in their higher oxidation state, whereas the solubility and mobility of metalloids depend on both the oxidation state and the ionic form (Ross, 1994). In the case of sediments and soils, As(III) can be oxidized to As(V) by bacteria (Bachate et al., 2012; Battaglia-Brunet et al., 2002). The strong affinity of $A s(V)$ towards inorganic soil components, results in the immobilization of As after the oxidation process. Under well drained conditions, As is usually present as $\mathrm{As}(\mathrm{V})$ in soils, whereas under reduced conditions, As(III) dominates in soils, but elemental arsenic $[\mathrm{As}(0)]$ and arsine $\left(\mathrm{H}_{2} \mathrm{As}\right)$ can also be present. The reduction and methylation reactions of As in sediments are generally mediated by bacterial degradation of organic matter coupled with reduction and use of sulfate as the terminal electron acceptor (Kim et al., 2002).

Contrastingly, in the case of $\mathrm{Cr}$, oxidation of $\mathrm{Cr}$ (III) to $\mathrm{Cr}(\mathrm{VI})$ can enhance $\mathrm{Cr}$ mobilization and bioavailability. It is primarily mediated abiotically through oxidizing agents such as $\mathrm{Mn}(\mathrm{IV})$, and to a lesser extent by Fe(III), whereas reduction of $\mathrm{Cr}(\mathrm{VI})$ to $\mathrm{Cr}(\mathrm{III})$ is mediated through both abiotic and biotic processes (Choppala et al., 2013). Chromate (Cr(VI)) can be reduced to Cr(III) in environments where a ready source of electrons (Fe(II)) is available. Suitable conditions for microbial $\mathrm{Cr}(\mathrm{VI})$ reduction occur where organic matter is present to act as an electron donor, and $\mathrm{Cr}(\mathrm{VI})$ reduction is enhanced under acidic rather than alkaline conditions (Choppala et al., 2013; Hsu et al., 2009; Figure 2).

In most living systems, heavy metal(loid)s generally undergoes reduction rather than oxidation. For example, Se undergoes reduction by chemical reductants such as sulfide or hydroxylamine, or biochemically by glutathione reductase (Zhang et al., 2004). In the case of $\mathrm{Hg}$, microorganisms, particularly bacteria play a major role in reducing reactive $\mathrm{Hg}$ (II) to non-reactive $\mathrm{Hg}(0)$, which may be subjected to volatilization losses. $\mathrm{Hg}(\mathrm{II})$ is reduced to $\operatorname{Hg}(0)$ by mercuric reductase, and the dissimilatory metal(loid) reducing bacterium Shewanella oneidensis has been shown to reduce $\mathrm{Hg}$ (II) to $\operatorname{Hg}(0)$, which requires the presence of electron donors (Wiatrwoski et al., 2006). 
Table 3. Oxidation-reductions reactions of metal(loid)s in soil.

\begin{tabular}{|c|c|c|}
\hline Metal(loid) & Redox reactions & References \\
\hline $\mathrm{Cr}(\mathrm{VI})$ & $\begin{array}{l}\text { Addition of organic amendments (e.g. poultry manure, } \\
\text { biosolids) enhanced the rate of Cr reduction in soil. The } \\
\text { extent of } \mathrm{Cr}(\mathrm{VI}) \text { was influenced by the amount of } \\
\text { dissolved organic carbon present in the soil and } \\
\text { amendments. }\end{array}$ & Bolan et al., 2003 \\
\hline $\mathrm{Cr}(\mathrm{VI})$ & $\begin{array}{l}\text { Presence of DOC in soil as a result of soybean meal and } \\
\text { rice bran addition, reduced resin extractable } \operatorname{Cr}(\mathrm{VI}) \text { in soil }\end{array}$ & Chiu et al., 2009 \\
\hline $\mathrm{Cr}(\mathrm{VI})$ & $\begin{array}{l}\text { Chromate leaching was reduced in soils in the presence of } \\
\text { elevated organic matter because of reduction followed by } \\
\text { retention on cation exchange sites or precipitation }\end{array}$ & Park et al., 2004 \\
\hline $\mathrm{Cr}(\mathrm{VI})$ & $\begin{array}{l}\text { Bacteria reduced most of } \mathrm{Cr}(\mathrm{VI}) \text { in anaerobic conditions } \\
\text { and lactate was more effective as a bio-stimulant for } \\
\text { reduction by acting as an electron source. }\end{array}$ & Banks et al., 2006 \\
\hline As & $\begin{array}{l}\text { The mixture of sewage sludge and poultry litter reduced } \\
\mathrm{As}(\mathrm{V}) \text { to more mobile and toxic } \mathrm{As}(\mathrm{III}) \text {. }\end{array}$ & $\begin{array}{l}\text { Jackson and Miller, } \\
1999\end{array}$ \\
\hline $\mathrm{Se}$ & $\begin{array}{l}\text { Application of both insoluble (casein) an soluble } \\
\text { (Casamino acids) to Se contaminated soil enhanced } \\
\text { dimethyl selenide production and subsequent removal of } \\
\text { Se from soil through volatilization }\end{array}$ & $\begin{array}{ll}\text { Zhang } & \text { and } \\
\text { Frankenberger } & \text { Jr., } \\
1999 & \end{array}$ \\
\hline
\end{tabular}

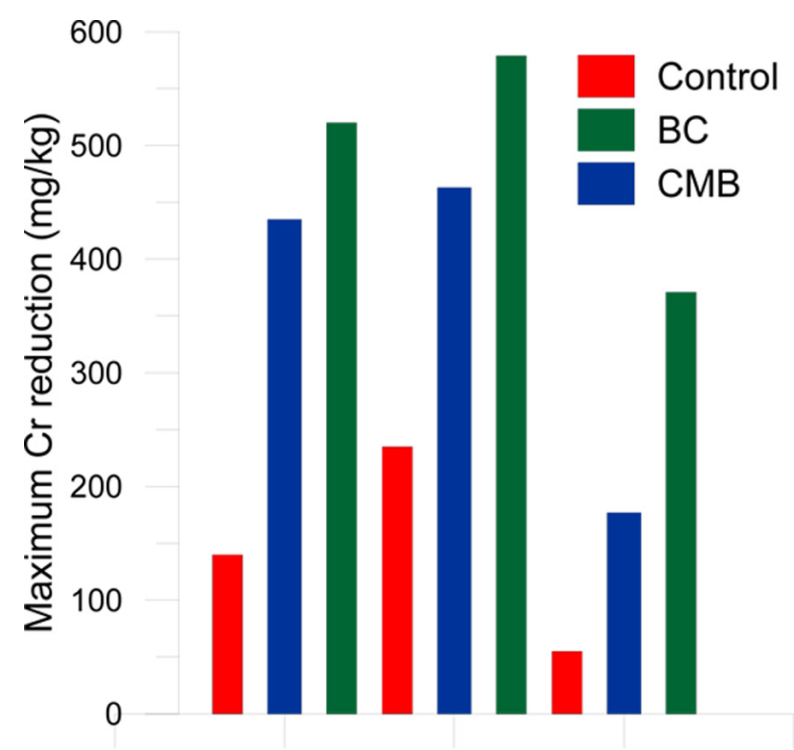

Soil 1 Soil 2 Soil 3

Figure 2. Effect of carbon based amendments on maximum $\mathrm{Cr}$ reduction $(\mathrm{mg} / \mathrm{kg})$ in three different types of soils (Choppala et al., 2013). Soil 1: Calcic red sandy loam; Soil 2: Calcic red clay; Soil 3: Tannery waste contaminated. Control: Unamended; 


\subsection{Methylation/Demethylation}

Another process of heavy metal(loid) transformation that occurs with the help of living system is methylation where toxic metal(loid) $\mathrm{s}$ are removed from soil by converting them to methyl derivatives that are subsequently removed by volatilization (Frankenberger and Losi, 1995). Methylated derivatives of $\mathrm{As}, \mathrm{Hg}$, and Se can originate from chemical and biological mechanisms and this frequently results in altered volatility, solubility, toxicity, and mobility. The major microbial methylating agents are methylcobalamin $\left(\mathrm{CH}_{3} \mathrm{CoB}_{12}\right)$, involved in the methylation of $\mathrm{Hg}$, and $\mathrm{S}$-adenosylmethionine (SAM), involved in the methylation of As and Se. Although methylation of metal(loid)s occurs through both chemical (abiotic) and biological processes, biological methylation (biomethylation) is considered to be the dominant process in soils and aquatic environments. Biomethylation may result in metal(loid) detoxification, since methylated derivatives may be excreted readily from cells, and are often volatile and may be less toxic, e.g., organoarsenicals.

Microorganisms in soils and sediments act as biologically-active methylators, where organic matter serves as a methyl donor for both biomethylation and abiotic methylation in soils and sediments (Frankenberger and Arshad, 2001; Loseto et al., 2004). For example, methylation of $\mathrm{Hg}$ is controlled by low molecular weight fractions of fulvic acid in soils (Battaglia-Brunet et al., 2002). Similarly, Lambertsson and Nilsson (2006) suggested that organic matter and alternative electron acceptors influenced methylation of $\mathrm{Hg}$ in the sediments. Mercury is methylated through both biotic and abiotic pathways, although microbial methylation mediated mainly through dissimilatory sulfate- and iron-reducing bacteria is generally regarded as the dominant environmental pathway (Rodriguez et al., 2004).

In the case of As, biomethylation is effective in forming volatile compounds such as alkylarsines, which could easily be lost to the atmosphere (Lehr, 2003; Yin et al., 2011). Methylated As species could result from direct excretion by algae or microbes or from degradation of the excreted arsenicals or more complex cellular organoarsenicals (Li et al., 2009).

Selenium biomethylation is of interest because it represents a potential mechanism for removing Se from contaminated environments, and it is believed that methylated compounds, such as dimethyl selenide (DMSe) are less toxic than dissolved Se oxyanions. Fungi are more active in the methylation of $\mathrm{Se}$ in soils, although some Se-methylating bacterial isolates have also been identified (Oremland et al., 2004). Dimethyl selenide can be demethylated in anoxic sediments as well as anaerobically by an obligate methylotroph similar to Methanococcides methylutens in pure culture. An anaerobic demethylation reaction may result in the formation of toxic and reactive $\mathrm{H}_{2} \mathrm{Se}$ from less toxic DMSe. Aerobic demethylation of DMSe is likely to yield $\mathrm{Se}(\mathrm{VI})$, thereby retaining Se in the system.

\section{The rhizosphere}

The rhizosphere, first described in 1904 by the German agronomist Lorentz Hiltner, has been the focus of intensive research for many years because of its importance in plant nutrition and pathogenesis. The importance of the rhizosphere has been well known for a long time as evidenced by the statements of Hiltner before an assembly of Deusche Landwirtschafts-Gesellschaf. Hiltner 
stated, "The nutrition of plants in general certainly depends upon the composition of the soil flora in the rhizosphere." He further admitted, "If plants have the tendency to attract useful bacteria by their root excretions, it would not be surprising if they would also attract uninvited guests which, like the useful organisms, adapt to root excretions. Nowadays, the research on rhizosphere has been directed towards its influence on the transformation of pollutants in soils (Vysloužilová et al., 2006, Yang et al., 2010). Anderson et al. (1993) stated, "Microbially mediated humification processes in the rhizosphere may have an important influence on the persistence and bioavailability of toxicants in surface soils".

The rhizosphere is a zone at the root-soil interface, controlled by plant root and root released metabolites, where a plethora of mutually interacting physical, chemical and biological processes operates within this zone. The health of both the plant and the soil associated is dependent on this rhizopshere region and its biochemical reactions. Although attempts have been made to unravel some of these processes, the understanding of the intricacies of this unique 'twilight zone' is still in its infancy. It is for this reason that noted microbiologists, G.D. Bowen and A. Rovira, correctly described the rhizosphere zone as - 'the hidden half of the hidden half'. Numerous research throughout the last hundred years helped in dividing rhizosphere into three zones based on their relative proximity to the root and their resultant influence (Figure 3). The endorhizosphere is the inner layer which includes cortex and endodermis, where microbes and cations (heavy metals) can occupy the space between cells. The rhizoplane or the middle layer consists of root epidermis and mucilage, found adjacent to the root. The ectorhizosphere is the outermost layer leading into the bulk soil. Plant root systems are inherently complex and diverse and hence rhizosphere is not a region of definable size or shape. However, it depends on the physical, chemical and biological properties of the rhizosphere region, which change both radially and longitudinally along the root (Fageria and Stone, 2006). For example, Cd accumulation occurs in most plants only in the roots but restricted to other parts of the plant (Nocito et al., 2011). Hence, physiological response by plants also play an important role in heavy metal resistance. In an experiment conducted by Sghayar et al. (2015), the role of thiol biosynthesis and metabolism were investigated for determining $\mathrm{Cd}$ tolerance in barley cultivars and they found strong effect on $\mathrm{Cd}$ accumulation.

The properties of rhizosphere vary according to the plant species, where the width has been shown to extend from $2-80 \mathrm{~mm}$ from the root surface. Concentration of root exudates and extent of microbial activity are useful indicators of demarcation of rhizosphere and bulk soil zone, generally termed as 'edaposphere'. Although the chemical and biological features help in identifying the rhizosphere, it is challenging to separate the zone physically from the surface of the root. There has been continuous efforts on determining the ideal ratio between rhizosphere and bulk soil known as R/E ratio, which was found to be between 2 and 20, which can be termed as rhizosphere effect (Badalucco and Kuikman, 2001). There have been abundant information on rhizosphere chemistry and biology, mainly targeting nutrients for agricultural production. However, research work on the role of rhizosphere and their mechanisms in remediating heavy metal(loid)s from soil are scattered and relatively less. 


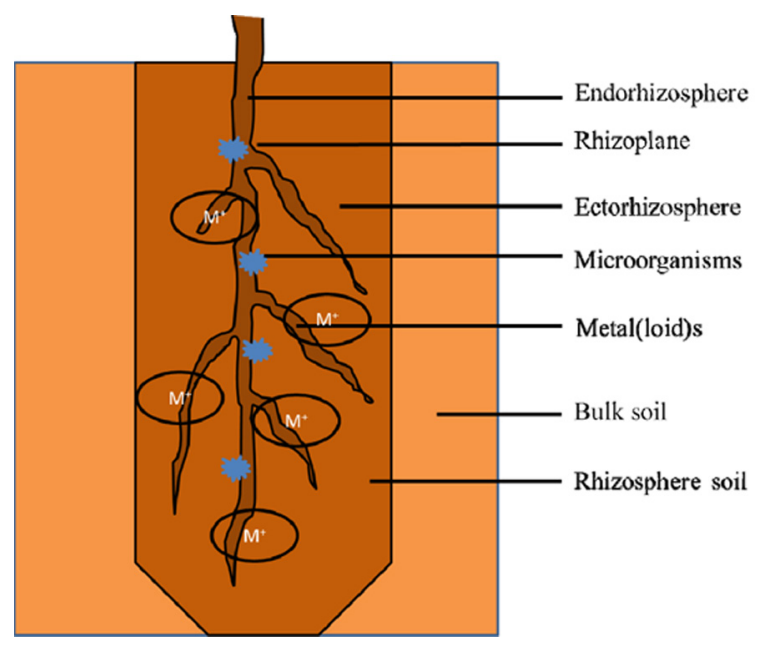

Figure 3. A section of soil showing bulk soil and rhizosphere soil with three regions of rhizosphere - Ectorhizosphere, rhizoplane and endorhizosphere (with metal(loid)s and microorganisms).

\section{The role of rhizosphere processes in phytoremediation}

Phytoremediation or plant-assisted bioremediation refers to the use of plants to:

- stabilise or immobilise contaminants in soils or sediments which can be termed as phytostabilisation or phytoimmobilisation, respectively

- volatilise some metals and metalloids by the formation of volatile compounds by the action of rhizosphere microorganisms or after uptake in plant organs - phyto-volatalisation/rhizo-volatalisation - extract metals / metalloids via uptake in harvestable plant parts, i.e. typically shoots, which can be termed as phytomining

- remove organic pollutants via microbial degradation in the plant rhizosphere or by metabolising them after uptake in plant organs phyto-degradation/rhizodegradation
Wenzel (2009) pointed out that the action of plant rhizosphere is one of the key factors in establishing phytoremediation crops under (typically) harsh conditions. Selection of suitable plants not only enable uptake of specific heavy metals (phytoextraction) but also helps in controlling the bioavailability of the pollutant (phytoimmobilisation) and thereby degradation through ageing (phytodegradation). Since the processes are initiated at the rhizosphere region, terminologies such as rhizoremediation, rhizodegradation and rhizovolatalisation can also be used, alternatively. There are numerous reviews on the rhizosphere action in phytoremediation over the past two decades (Anderson et al., 1993; Anderson and Coats, 1994; Dzantor, 2007; Fitz and Wenzel, 2002; Kuiper et al., 2004; McGrath et al., 2001; Meharg and Cairney, 2000; Newman and Reynolds, 2004; Siciliano and Germida, 1998; 
Wenzel, 2009). There are four main factors that influences rhizosphere processes - (1) rhizosphere modification; (2) $\mathrm{pH}$; (3) root exudates and (4) microbial activity. These factors can act both independently and also in a coordinated way.

\section{a. Rhizoshpere modification}

Roots react to both the physical (e.g. presence or absence of water) and chemical changes (e.g. nutrients) in the soil environment. The response of roots not only affects the plants but also the soil in the rhizosphere region, thereby bringing in changes to the $\mathrm{pH}$, chemical equilibrium of the rhizosphere soil and microbial activity in the region. Addition of nutrients and/or organic amendments to the soil can affect the chemistry (e.g., pH, organic acids, soil solution composition) and biology (e.g., microbial community) of soil (Park et al., 2011). The changes in soil chemistry due to soil amendment and plant growth can therefore influence the transformation, mobility and bioavailability of metal(loid)s (Walker et al., 2003; Clemente et al., 2010). The effect of organic amendments on some of the rhizosphere properties in relation to metal(loid)s dynamics is presented in Table 4. In the case of nutrients such as phosphorus (P), plant response to As and $\mathrm{P}$ interactions in the root zone appears to be system dependent. In nutrient solution culture, increasing amounts of soluble $\mathrm{P}$ at fixed As concentration reduced As phytotoxicity (Rumberg et al., 1960). This was attributed to the inhibition of As uptake by roots in the presence of excessive amounts of $P$. Whereas in soil systems, P fertilizer addition has been shown to enhance the uptake of As due to an increase in solubility of As. This was because of competitive adsorption of phosphate to soil components such as $\mathrm{Fe}$ and $\mathrm{Al}$ and the resultant desorption of $\mathrm{As}$ (Creger and Peryea, 1994; Peryea, 1991). Hence, $\mathrm{P}$ retention in soil plays an important role in As adsorption.

Generally, plants respond to nutrient deficiency by changing the structure of roots, altering the chemical environment in the rhizosphere region or recruiting the help of microorganisms. While the presence/absence of nutrients and water influences the root morphology, the exudates from the roots alter the chemical equilibrium of the root region by acidifying or changing the redox conditions within the rhizosphere or directly chelating with the nutrient. Exudates can liberate nutrients via dissolution of insoluble mineral phases or desorption from clay minerals or organic matter where they are released into soil solution and can then be taken up by the plant. The most limiting nutrients to plant growth are nitrogen $(\mathrm{N})$ and $(\mathrm{P})$. Even though $78 \%$ of the Earth's atmosphere is composed of nitrogen $\left(\mathrm{N}_{2}\right.$ gas), it is in a form that is only utilizable by nitrogen-fixing organisms. As such, inorganic forms of $\mathrm{N}\left(\mathrm{NO}_{3}^{-}, \mathrm{NH}_{4}^{+}\right)$that can be used by plants are added to soils. Plants respond differently depending on the form of nitrogen in the soil. Ammonium has a positive charge, and thus the plant expels one proton $\left(\mathrm{H}^{+}\right)$for every $\mathrm{NH}_{4}^{+}$ taken up resulting in a reduction in rhizosphere $\mathrm{pH}$. When supplied with $\mathrm{NO}_{3}^{-}$, the opposite can occur where the plant releases bicarbonate $\left(\mathrm{HCO}_{3}\right.$ ) which increases rhizosphere $\mathrm{pH}$. These changes in $\mathrm{pH}$ can influence the availability of other plant essential micronutrients (e.g., $\mathrm{Zn}, \mathrm{Ca}, \mathrm{Mg}$ ). 
Table 4. Selected references on rhizosphere modifications in relation to heavy metal(loid)s remediation in soil as affected by organic amendments.

\begin{tabular}{|c|c|c|c|}
\hline $\begin{array}{l}\text { Organic } \\
\text { amendments }\end{array}$ & $\begin{array}{l}\text { Mode of } \\
\text { action }\end{array}$ & Observations & References \\
\hline Biosolid & $\mathrm{pH}$ & $\begin{array}{l}\text { The application of biosolids decreased } \mathrm{pH} \text { of pore water of } \\
\text { rhizosphere soil of Lolium perenne. }\end{array}$ & Santibanez et al., 2008 \\
\hline Sugarbeet & $\mathrm{pH}$ & $\begin{array}{l}\text { Mixed amendment of sugarbeet, Aspergillus niger and rock } \\
\text { phosphate significantly decreased } \mathrm{pH} \text { in the rhizosphere of Cistus } \\
\text { albidus. }\end{array}$ & Caravaca et al., 2005 \\
\hline Humic acid & Organic acid & $\begin{array}{l}\text { Application of humic acid increased bioavailability of various heavy } \\
\text { metal(loid)s and enhanced their translocation from root to shoot. }\end{array}$ & Bandiera et al., 2009. \\
\hline Biosolids & Organic acid & $\begin{array}{l}\text { Biosolids enhanced the organic acid production in the rhizosphere of } \\
\text { the Zea mays. }\end{array}$ & Koo et al., 2006 \\
\hline Crop residues & $\begin{array}{l}\text { Microbial } \\
\text { activity }\end{array}$ & $\begin{array}{l}\text { Soils amended with crop residues increased microbial diversity in } \\
\text { wheat rhizosphere }\end{array}$ & Nelson and Mele, 2006 \\
\hline $\begin{array}{l}\text { Food waste } \\
\text { compost }\end{array}$ & $\begin{array}{l}\text { Microbial and } \\
\text { enzyme } \\
\text { activity }\end{array}$ & $\begin{array}{l}\text { Application of food waste compost significantly increased bacterial } \\
\text { an fungal populations, soil enzyme activities in lettuce rhizosphere }\end{array}$ & Lee et al., 2004 \\
\hline $\begin{array}{l}\text { Soluble organic } \\
\text { carbon }\end{array}$ & $\begin{array}{l}\text { Microbial } \\
\text { activity }\end{array}$ & $\begin{array}{l}\text { Structural manipulation of rhizobacterial communities can be } \\
\text { mediated by artificial exudates in the form of soluble organic carbon }\end{array}$ & Baudoin et al., 2003 \\
\hline Wheat straw & $\begin{array}{l}\text { Microbial } \\
\text { activity }\end{array}$ & $\begin{array}{l}\text { Addition of organic amendments significantly enhanced the microbial } \\
\text { population in wheat rhizosphere }\end{array}$ & Barakah et al., 1995 \\
\hline Humic acid & $\begin{array}{l}\text { Enzyme } \\
\text { activity }\end{array}$ & $\begin{array}{l}\text { Application of humic acids increased plasma membrane H+ ATPase } \\
\text { activity in the root of Zea mays seedlings }\end{array}$ & Canellas et al., 2002. \\
\hline
\end{tabular}

\section{b. Rhizosphere $\mathrm{pH}$}

Rhizosphere $\mathrm{pH}$ is generally acidic and it can be attributed to a combination of mechanisms, including: (i) cation-anion exchange balance; (ii) organic acid release (e.g., citric, malaeic, lactic, oxalic, propanic, butyric acids); (iii) root exudation and respiration and (iv) redox-coupled processes involving changes in the oxidation state of $\mathrm{Fe}, \mathrm{Mn}$ and $\mathrm{N}$ and consuming or producing of $\mathrm{H}^{+}$(Hinsinger et al., 2003). Application of organic amendments such as biosolids and manures can also produce organic acids extracellularly due to organic matter breakdown and often decreases the $\mathrm{pH}$ of rhizosphere soils (Caravaca et al., 2005; Santibanez et al., 2010). However, the contribution of organic acid exudation to the $\mathrm{pH}$ of soil solutions depends on the soil $\mathrm{pH}$, the assemblage of organic acids, and to some extent the ionic strength of the soil solution (Jones, 1998). One of the mechanisms behind rhizosphere acidification is the release of $\mathrm{H}^{+}$by roots in their immediate vicinity (Ernst, 1996). Javed et al. (2013) studied the rhizopshere $\mathrm{pH}$ and exudates of Eriophorum angustifolium (cotton grass) and found that although root exposure of 2-25 ng/g Pb, Cu, $\mathrm{Zn}$, As and $\mathrm{Cd}$ induced higher exudation of organic acids, but they did not influence the changes in $\mathrm{pH}$. This was attributed to other organic molecules such as polypeptides (Wheeler and Irving, 2010). Within the rhizosphere, soil acidification is mainly caused by an imbalance in the carbon and nitrogen cycles caused by uptake of cations-anions and respiration (Tang et al., 2005). A major source of $\mathrm{H}^{+}$fluxes in the rhizosphere is related to the differential uptake of cations and anions by plant roots (Hinsinger et al., 2003; Zhang et al., 2009; Ryan et al., 1993). Uptake of solution $\mathrm{NH}_{4}^{+}$results in a loss of positive charge in solution, which is counter-balanced by a corresponding release of $\mathrm{H}^{+}$into the rhizosphere (Marschner, 1995). Apart from this, $\mathrm{N}$ transformation and nitrate leaching have been suggested to be major causes of soil acidification (Bolan et al., 1991). The crop type also plays a major role in rhizosphere acidification. Nitrogen fixing plants tend to decrease soil $\mathrm{pH}$ more than non-N fixing plants, since the alkaline release does not occur significantly as $\mathrm{NO}_{3}$ - is not required. Tang et al. (2000) reported that the lupin (Lupinus angustifolius) and 
subterranean clover (Trifolium subterraneum) without receiving nitrogen fertilizer produced approximately $1.4 \mathrm{mmol} \mathrm{H}^{+}$per $\mathrm{kg}$ soil over the experimental period, on average. The impact of plant on the rhizosphere also varies temporally, and at different points along the plant root (Marschner, 1995).

Although metal(loid) uptake by plants is known to decrease with decreasing $\mathrm{pH}$ in nutrient culture, metal(loid) uptake increases in the soil environment (Weng et al., 2003; 2004). This can be attributed to competitive adsorption of metal(loid)s with soil components, thereby increasing the chances of metal(loid) desorption. For example, higher Cd uptake was obtained for lettuce (Lactuca sativa) and Swiss chard (Beta vulgaris) grown on acid soils ( $\mathrm{pH} 4.8$ to 5.7) than on calcareous soils (pH 7.4 to 7.8) (Mahler et al., 1978). Khan and Jones (2009) showed that the addition of lime resulted in the largest reduction in metal extractability with diethylene triamine pentaacetic acid and $\mathrm{Ca}\left(\mathrm{NO}_{3}\right)_{2}$ and phytoavailability of $\mathrm{Cu}, \mathrm{Fe}$ and $\mathrm{Zn}$.

In addition to bioavailability of metal(loid)s to plants, acidification also affects the leaching and residence time of many metal(loid)s in soil. Tyler (1978) observed that the amount of metal(loid)s released from the mor soils of Sweden increased with decreasing $\mathrm{pH}$. Approximately $85 \%$ of the total $\mathrm{Cd}$ was released from the soil at $\mathrm{pH} 2.8$. The time needed for a $10 \%$ decrease in the total concentration of $\mathrm{Cd}$ in the mor horizon through leaching was estimated to be 1.7 years at a $\mathrm{pH}$ of $2.8,4-5$ years at a $\mathrm{pH}$ of 3.2 , and 20 years at a $\mathrm{pH}$ of 4.2 .

\section{1..Root exudates}

Apart from the morphological changes and $\mathrm{pH}$ dynamics, plant roots also respond chemically by releasing organic compounds such as carbohydrates, organic acids (carboxylic and amino acids) and protons which are termed as root exudates and the process being 'Rhizodeposition'. The exudates are generally water-soluble and includes secretions, lysates, gases and mucilage (Grayston et al., 1997). These rhizodeposits are mainly $\mathrm{C}$ based compounds (e.g. organic acids) and hence attract microorganisms fuelling additional microbial growth within the rhizosphere (Lynch and Whipps, 1990). Tao et al. (2004) evaluated the root induced changes in the transformation of $\mathrm{Cu}$ and concluded that the exudation of organic compounds can influence the behavior of trace and toxic metals.

Certain low molecular-weight compounds released from plant roots (amino acids, carboxylic acids, sugars, and simple and flavonoid-type phenolics) (Uren, 2007) may form stable complexes with metal cations in the soil solution matrix, and can directly modify metal(loid) availability in the rhizosphere (Jones, 1998). The role of carboxylates has been examined for their potential impact on the biogeochemistry of metals through aqueous complexation and ligand exchange processes. Amongst the range of carboxylates exuded in the rhizosphere, malate, citrate and oxalate are expected to have the most dramatic effect due to their ability for complexation of metal(loid)s (Hinsinger, 2001). In a study by Bolan et al. (2013) on native Australian vegetation (grass, shrub and trees), organic acid exudated from the roots have reduced $\mathrm{Cr}$ and $\mathrm{As}$. In the case of $\mathrm{Cr}$, reduction was negatively correlated to bioavailability whereas the reduction of As from $\mathrm{V}$ to As (III) increased its bioavailability which can also be attributed to the reduction induced $\mathrm{pH}$ increase.

Organic exudates are also released from the roots when the plant is under stress from mineral deficiency and toxicity (Jones, 1998; Marschner, 1995). Iron deficiency has been known to induce root exudation of range of organic compounds to improve $\mathrm{Fe}$ acquisition in soils (Jones, 1998; Rengel, 1997; 2002). Exudation of siderophores, another organic 
exudate, is an additional strategy utilized by plants under Fe deficiency (Crowley and Rengel, 1999). The siderophores released by plants for the purpose of $\mathrm{Fe}$ chelation are termed as phytosiderphores. Phosphorus deficiency is also well known to result in organic anion exudation in a range of plant species (Jones, 1998; Marschner, 1995; Pearse et al., 2006; 2007). The release of organic acids such as oxalate, malate and piscidate is hypothesized to increase $\mathrm{P}$ sequestration from mineral surfaces; however, organic exudates production does not necessarily result in greater $\mathrm{P}$ uptake (Pearse et al., 2007). Root exudate production has also been shown in response to metal(loid) exposure in soil solution (Jones, 1998; Bertin et al., 2003; Das and Maiti, 2007). Bao et al. (2011) demonstrated the effect of $\mathrm{Cd}$ concentration on exudation of organic acids by the roots of Solanum nigrum and showed that an increase in Cd concentration in soil, increased the overall concentration of organic acids (Figure 4). The exudation of organic acids by plants or associated microbes may complex metal(loids) and reduce uptake, although increased uptake is more commonly observed with artificial introduction of organic acids (Zhao et al., 2001). Studies show that $\mathrm{Al}$ and some heavy metals can elicit organic acid exudation in roots. Nian et al. (2002) compared Al induced organic acid exudation in wheat plants with that of $\mathrm{Cu}$ 's effect and found that the $\mathrm{Cu}$ also induced an efflux of organic acid exudation, thereby playing a role in alleviating $\mathrm{Cu}$ toxicity in plants.

The promotion of root growth by improvement of soil physical, chemical and biological conditions is also likely to enhance the further modification of metal(loid) behaviour in the rhizosphere (Farinati et al., 2009). Koo et al. (2006) found the total organic acid concentration was highest when biosolid and plant growth was combined, rather the single treatment. The biosolid provided a baseline of a wide range of organic acids, although the organic acid composition changed considerably with addition of plants. However, the combined effect was greater than the single roles, possibly due to additional root growth. The interaction of organic amendments with the rhizosphere depends on the nutrient content, heavy metal(loid) availability and the ability of plant species to tolerate heavy metal(loid) exposure, however, limited data exists to date.

Organic amendments (compost, compost water extract, the hydrophobic and hydrophilic fractions of the DOC extracted from the compost) increased available $\mathrm{C}$ compounds in the rhizosphere soils amended. Organic amendments enhanced organic $\mathrm{C}$ release by maize plant roots. Similar observations were made by Caravaca et al. (2002), who reported an increased rhizodeposition in Olea europaea sub sp. sylvestris and Rhamnus lycioides treated with composted residue. Caravaca et al. (2005) demonstrated that sugar beet-residue amendment increased the total carbohydrates and soluble C-fraction (water-soluble $\mathrm{C}$ and water-soluble carbohydrates) in the rhizosphere of Cistus albidus L. and Quercus coccifera L.

\section{c. Microbial activity}

Root exudates not only deposits the C compounds in the rhizosphere region and alter the chemical composition of the rhizosphere soil, but also serve as food for microorganisms (Brant et al., 2006). Singh et al. (2007) hypothesised that plants select for beneficial microbial communities in their rhizosphere by releasing certain metabolites targeting specific microbes. While penetrating into the soil, root tips exert tremendous pressure $\left(>7 \mathrm{~kg} / \mathrm{cm}^{2}\right)$, thereby ensuring smooth growth. The epidermal cells also secrete a viscous, high molecular weight insoluble substance called mucilage, which not only lubricates the root tips but also assists the plants in nutrient acquisition and improves soil quality by increasing water infilteration 
and aeration (Bengough and McKenzie, 1997). This mucilage also attracts beneficial microorganisms an serves as a bait for root pathogens, where oxidation/ reduction of metal(loid)s takes place to sequester the metal(loid)s (Hawes et al., 2000).

Numerous studies indicate higher solubility of heavy metal(loid)s such as $\mathrm{As}, \mathrm{Cu}, \mathrm{Zn}$, and $\mathrm{Pb}$ in soils with plants than control soil without plants, which can be attributed to exudates forming soluble complexes with the metal(loid)s. For example, Banuelos and Lin (2007) conducted a field study on the effect of methionine on Se transformation and found higher rates of volatile $\mathrm{Se}$ in vegetated plots compared to the control plots. They attributed the transformation to additional microbial activity as effected by root exudates of the plants. Bolan et al. (2013) observed that increased microbial activity in the rhizosphere of native vegetation contributed to the reduction in the concentration of As and Cr. In this regard, it is well known that plants produce root exudates containing organic acid anions, sugars, vitamins, amino acids, inorganic ions, and some enzymes, which likely have substantial impacts on microbial population development and biological activity. Hence, the interaction between plant roots and soil microbes can enhance metal bioavailability in rhizosphere.

Apart from the plant roots, some prokaryotic (bacteria, archaea) and eukaryotic (algae, fungi) microorganisms can also excrete extracellular polymeric substances (EPS), such as polysaccharides, glucoprotein, siderophores, lipopolysaccharide, soluble peptide etc. These substances possess a substantial quantity of functional groups which can coordinate with metal(loid) ions. A number of microbes are involved in EPS production viz., Bacillus megaterium, Acinetobacter, Pseudomonas aeruginosa, SRB, soil fungi and cyanobateria (Satpute et al., 2010; Flemming and Wingender, 2001; Suh et al., 1999; Domozych et al., 2005; Domozych, 2007).
Similar to the endorhizosphere of plant roots, the cell wall of microbes also plays a major role in metal(loid) adsorption/reduction (Hall, 2002). Some studies have even proposed complexation, ion exchange, adsorption (by electrostatic interaction or van der Waals force), inorganic precipitation, oxidation and/ or reduction as part of metal uptake mechanisms by organisms (Volesky, 1990; Pietrobelli et al., 2009). In metal(loid) contaminated soil, the poor performance of plant growth and root development are major limiting factors for phytoaccumulation of metal(loid) s. To overcome these problems, improvement of the microbial activity in rhizosphere in addition of organic amendments is necessary. Plant growth promotion mechanisms by indole acetic acid (IAA), siderophores and 1-aminocyclopropane-1-carboxylate (ACC) deaminase producing microbes in the presence of metal are not well known. Most of recent studies assume that demonstrating the presence of all or even some of these activities is sufficient to elaborate the mechanisms. These findings suggest that (i) IAA promotes plant growth per se (Patten and Glick, 2002), (ii) ACC deaminase prevents the stress by-product ethylene which inhibits plant growth (Penrose et al., 2001) and (iii) siderophores help plants to acquire sufficient $\mathrm{Fe}$ in the presence of overwhelming amounts of other (potentially competing) metal(loid)s (Burd et al., 2000). The Ni resistant ACC deaminase-containing plant growth-promoting bacterium could decrease the toxicity of Ni to canola plants (Burd et al., 1998), there have been a large number of reports of facilitation of metal(loid) phytoextraction through the addition of plant growth-promoting bacteria and fungi. A number of scientific evidences proved that the inoculation of plant growth-promoting bacteria facilitated plant growth and increased the uptake of metal(loid) by the plant (Rajkumar et al., 2006; Ma et al., 2009; Sheng and Xia, 2006). Pii et al. (2015) highlighted that plant growth promoting bacteria can positively affect the 
plants at both physiological and molecular levels (e.g. inducing rhizosphere acidification, genetic regulation of ion uptake).

In soil, heavy metal(loid)s can have long-term toxic effects within ecosystems (Oleiveira and Pampulha, 2006) and have a negative influence on biologically mediated soil processes (Lee et al., 2002). It is generally accepted that accumulation of metal(loids) reduces soil microbial biomass (Yang et al., 2007) and various enzyme activities, leading to a decrease in the functional diversity in the soil ecosystem (Crowley, 2008) and changes in the microbial community structure. However, metal(loid) exposure may also lead to the development of metal(loid) tolerant microbial populations (Ellis et al., 2003). For example, many microbes have been reported to reduce $\mathrm{Cr}(\mathrm{VI})$ under aerobic and anaerobic condition. Bio-reduction of $\mathrm{Cr}(\mathrm{VI})$ can be directly achieved as a result of microbial metabolism (Nancharaiah et al., 2010) or indirectly achieved by a bacterial metabolites such as $\mathrm{H}_{2} \mathrm{~S}$ (Okeke, 2008). Therefore, $\mathrm{C}$ based root exudates along with rhizodeposition induced microbial metabolism can enhance rhizosphere process thereby influencing metal(loid) transformation in the rhizosphere region. Phytoremediation strategies can be drawn based on the root exudate and the resultant microbial metabolites for restoring metal contaminated sites.

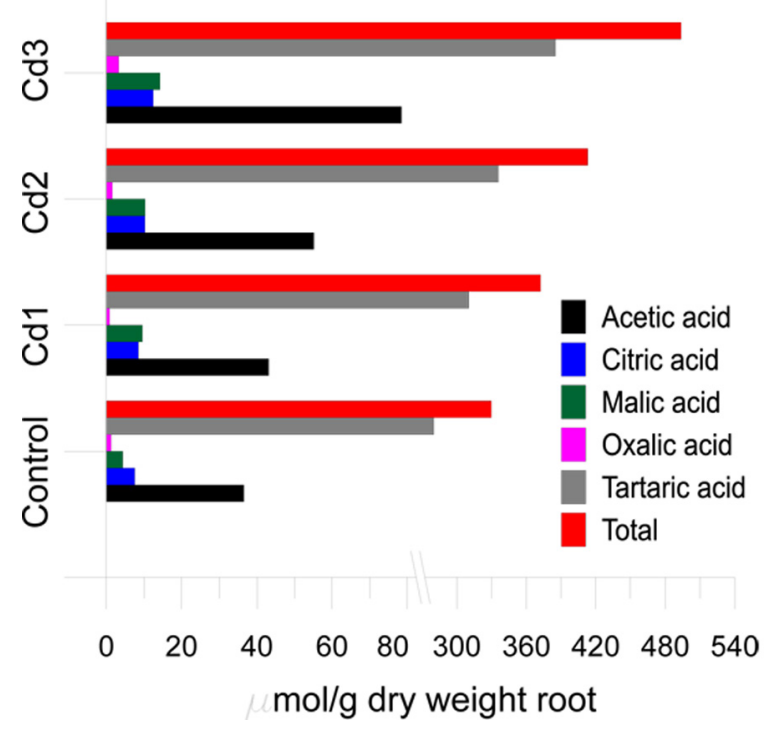

Figure 4. Exudation of some low molecular organic acids by roots of Solanum nigrum as affected by varying Cd concentration in soil (Bao et al., 2011). Control: No Cd (0 mg/kg); Cd1: $1 \mathrm{mg} / \mathrm{kg} ; \mathrm{Cd} 2: 5 \mathrm{mg} / \mathrm{kg} ; \mathrm{Cd} 3: 10 \mathrm{mg} / \mathrm{kg}$

\section{Conclusion}

Plant pathologists have been very active in research relating to rhizosphere influence on the infection of a number of root diseases. Soil scientists on the other hand seem to have neglected the importance of rhizosphere in the transformation of nutrients and contaminants in soil. A greater understanding of the biological (microbial activity) and chemical (exudates) changes in the rhizosphere will enable us to identify the processes involved in the mobilisation of nutrients and heavy metals added to soils. 
Further study is required to describe the ecological and physiological characteristics of the microbial communities associated with plant roots and to identify the zone of influence of various plant species in relation to remediation of heavy metals.

Plant roots are known to provide not only physical support to the plants, but also help at absorbing moisture and acquisition of nutrients. The region around root and soil is a dynamic interface of several biogeochemical processes as mediated by exudation of chemicals and resultant microbial activity. Understanding and utilising these interactions for heavy metal remediation on a contaminated land is a challenge for generations to come. With the advent of new and precise technologies (e.g. high resolution imaging) for rhizosphere observation and analyses, developing reliable technologies for heavy metal remediation at field level requires collaboration of soil scientists, microbiologists, plant biologists and mathematicians.

\section{Acknowledgement}

The authors would like to thank the Cooperative Research Centre for Contamination Assessment and Remediation of the Environment (CRC CARE), Australia for funding this research work in collaboration with University of South Australia, Mawson Lakes Campus, South Australia, Australia.

\section{References}

Adriano, D.C. 2001. Trace elements in terrestrial environments: Biogeochemistry, bioavailability and risks of metals. 2nd ed., Springer, New York.

Adriano, D.C., Wenzel, W.W., Vangronsveld, J., Bolan, N.S. 2004. Role of assisted natural remediation in environmental cleanup. Geoderma. 122, 121-142.
Anderson, T.A., Coats, J.E. 1994. Bioremediation through rhizosphere technology. ACS Symp Ser: 563. Am. Chem. Soc., Washington, DC.

Anderson, T.A., Guthrie, E.A., Walton, B.T. 1993. Bioremediation in the rhizosphere: Plant roots and associated microbes clean contaminated soil. Environ. Sci. Technol. 27, 2630-2636.

Armienta, M.A., Rodriguez, R., Cruz, O. 1997. Arsenic content in hair of people exposed to natural arsenic polluted groundwater at Zimapan, Mexico. Bull. Environ. Contam. Toxicol. 59, 583-589.

Bachate, S.P., Khapare, R.M., Kodam, K.M. 2012. Oxidation of arsenite by two $\beta$-proteobacteria isolated from soil. Appl. Microbiol. Biotechnol. 93, 2135-2145.

Badaluco, L., Kuikman, P.J. 2006. Mineralization and immobilization in the rhizosphere. In: Pinton, R., Varanini, Z., Nannipieri, P (Eds.) The Rhizosphere: Biochemistry and organic substances at the soil-plant interface. Marcel Dekker, NewYork. pp. 141-196.

Bandiera, M., Mosca, G., Vamerali, T. 2009. Humic acids affect root characteristics of fodder radish (Raphanus sativus L. var. oleiformis Pers.) in metal-polluted wastes. Desalination. 246, 78-91.

Banks, M.K., Schwab, A.P., Henderson, C. 2006. Leaching and reduction of chromium in soil as affected by soil organic content and plants. Chemosphere. 62, 255-264.

Banuelos, G.S., Lin, Z.Q. 2007. Acceleration of selenium volatilization in seleniferous agricultural drainage sediments amended with methionine and casein. Environ. Pollut. 150(3), 306-312.

Bao, T., Sun, T., Sun, L. 2011. Low molecular weight organic acids in root exudates and cadmium accumulation in cadmium hyperaccumulator Solanum nigrum L. and non-hyperaccumulator Solanum lycopersicum L. Afr. J. Biotechnol. 10(75), 17180-17185. 
Barakah, F.N., Salem, S.H., Heggo, A.M., BinShiha, M.A. 1995. Activities of rhizo-sphere microorganisms as affected by application of organic amendments in a calcareous loamy soil. 2. Nitrogen transformations. Arid Land Res. Manag. 9, 467-480.

Battaglia-Brunet, F., Dictor, M.C., Garrido, F., Crouzet, C., Morin, D., Dekeyser, K., Clarens, M., Baranger, P. 2002. An arsenic (III)-oxidizing bacterial population: selection, characterization, and performance in reactors. J. Appl. Microbiol. 93, 656-667.

Baudoin, E., Benizri, E., Guckert, A. 2003. Impact of artificial root exudates on the bacterial community structure in bulk soil and maize rhizosphere. Soil Biol. Biochem. 35, 1183-1192.

Bengough, A.G., McKenzie, B.M. 1997. Sloughing of root cap cells decreases the frictional resistance to maize (Zea mays L.) root growth. J. Exper. Bot. 48, 885-893.

Bertin, C., Yang, X., Weston, L.A. 2003. The role of root exudates and allelochemicals in the rhizosphere. Plant Soil. 256, 67-83.

Bolan, N.S., Thiyagarajan, S. 2001. Retention and plant availability of chromium in soils as affected by lime and organic amendments. Aust. J. Soil Res. 39, 1091-1103.

Bolan, N.S., Adriano, D.C., Kunhikrishnan, A., James, T., McDowell, R., Senesi, N. 2011. Dissolved organic carbon: biogeochemistry, dynamics and environmental significance in soils. Adv. Agron. $110,1-75$.

Bolan, N.S., Adriano, D.C., Mani, P., Duraisamy, A., Arulmozhiselvan, S. 2003. Immobilization and phytoavailability of cadmium in variable charge soils: I. Effect of phosphate addition. Plant Soil. 250, 83-94.
Bolan, N.S., Choppala, G., Kunhikrishnan, A., Park, J.H., Naidu, R. 2013. Microbial transformation of trace elements in soils in relation to bioavailability and remediation. Rev. Environ. Contam. Toxicol. $225,1-56$.

Bolan, N.S., Hedley, M.J., White, R.E. 1991. Processes of soil acidification during nitrogen cycling with emphasis on legume based pastures. Plant Soil. 134, 53-63.

Bolan, N.S., Naidu, R., Syers, J.K., Tillman, R.W. 1999. Surface charge and solute interactions in soils. Adv. Agron. 67, 88-141.

Bolan, N.S., Kunhikrishnan, A., Gibb, J. 2013. Rhizoreduction of arsenate and chromate in Australian native grass, shrub and tree vegetation. Plant Soil. 367(1-2), 615-625.

Brant, J.B.,Myrold, D. D., Sulzman, E.W. 2006. Root controls on soil microbial com-munity structure in forest soils. Oecologia. 148, 650-659.

Burd, G.I., Dixon, D.G., Glick, B.R. 1998. A plant growth-promoting bacterium that decreases nickel toxicity in seedlings. Appl. Environ. Microbiol. 64, 3663-3668.

Burd, G.I., Dixon, D.G., Glick, B.R. 2000. Plant growthpromoting bacteria that decrease heavy metal toxicity in plants. Can. J. Microbiol. 46, 237-245.

Canellas, L.P., Olivares, F.L., Okorokova-Facanha, A.L., Facanha, A.R. 2002. Humic acids isolated from earthworm compost enhance root elongation, lateral root emer-gence, and plasma membrane $\mathrm{H}$ -ATPase activity in maize roots. Plant Physiol. 130, 1951-1957.

Caravaca, F., Alguacil., M.M., Azcon, R., Paralade, J., Torres, P., Roldan, A. 2005. Establishment of two ectomycorrhizal shrub species in a semiarid site after "in situ" amendment with sugar beet, rock phosphate and Aspergillus niger. Microb. Ecol. $49,73-82$. 
Caravaca, F., Hernandez, T., Garcia, C., Roldan, A. 2002. Improvement of rhizosphere aggregate stability of afforested semiarid plant species subjected to mycorrhizal inoculation and compost addition. Geoderma. 108, 133-144.

Chiu, C.C., Cheng, C.J., Lin, T.H., Juang, K.W., Lee, D.Y. 2009. The effectiveness of four organic matter amendments for decreasing resinextractable $\mathrm{Cr}$ (VI) in $\mathrm{Cr}$ (VI)-contaminated soils. J. Hazard. Mater. 161, 1239-1244.

Choppala, G.K., Bolan, N.S., Kunhikrishnan, A., Skinner, W., Seshadri, B. 2013. Concomitant reduction and immobilization of chromium in relation to its bioavailability in soils. Environ. Sci. Pollut. Res. DOI 10.1007/s11356-013-16536.

Clemente, R., Hartley, W., Riby, P., Dickinson, N.M., Lepp, N.W. 2010. Trace element mobility in a contaminated soil two years after fieldamendment with a greenwaste compost mulch. Environ. Pollut. 158, 1644-1651.

Creger, T.L., Peryea, F.J. 1994. Phosphate fertilizer enhances arsenic uptake by apricot liners grown in lead-arsenic-enriched soil. Hort. Sci. 29, 88-92.

Crowley, D. 2008. Impacts of metals and metalloids on soil microbial diversity and ecosystem function. Revista de la ciencia del suelo y nutrición vegetal. 8, 6-11.

Crowley, D.E., Rengel, Z. 1999. Biology and chemistry of rhizosphere influencing nutrient availability. In: Rengel, Z. (Ed.), Mineral Nutrition of Crops: Fundamental Mechanisms and Implications. The Haworth Press, New York, $1-40$.

Das, M., Maiti, S.K. 2007. Metal accumulation in A. baccifera growing naturally on abandoned copper tailings pond. Environ. Monit. Assess. 127, 119-125.
Del Razo, L.M., Arellano, M.A., Cebrian, M.E. 1990. The oxidation states of arsenic in well-water from a chronic arsenicism area in northern Mexico. Environ. Pollut. 64, 143-153.

Domozych, D.S. 2007. Exopolymer production by the green alga Penium margaritaceum: implications for biofilm residency. Int. J. Plant Sci. 168, 763774.

Domozych, D.S., Kort, S., Benton, S., Yu, T. 2005 The extracellular polymeric substance of the green alga Penium margaritaceum and its role in biofilm formation. Biofilms. 2, 129-144.

Dzantor, E.K. 2007. Phytoremediation: the state of rhizosphere "engineering" for accelerated rhizodegradation of xenobiotic contaminants. J. Chem. Technol. Biotechnol. 82, 228-232.

Ellis, R.J., Morgan, P., Weightman, A.J., Fry, J.C. 2003. Cultivation-dependent and independent approaches for determining bacterial diversity in heavy metal-contaminated soil. Appl. Environ. Microbiol. 69, 3223-3230.

Ernst, W.H.O. 1996. Bioavailability of heavy metals and decontamination of soils by plants. Appl. Geochem. 11, 163-167.

Fageria, N.K., Stone, L.F. 2006. Physical, chemical and biological changes in the rhizosphere and nutrient availability. J. Plant Nutr. 29, 1327-1356.

Farinati, S., DalCorso, G., Bona, E., Corbella, M., Lampis, S., Cecconi, D., Polati, R., Berta, G., Vallini, G., Furini, A. 2009. Proteomic analysis of Arabidopsis halleri shoots in response to the heavy metals cadmium and zinc and rhizosphere microorganisms. Proteomics. 9, 4837-4850.

Fitz, W.J., Wenzel, W.W. 2002. Arsenic transformations in the soil-rhizosphere-plant system: fundamentals and potential application to phytoremediation. J. Biotechnol. 99, 259-278. 
Flemming, H., Wingender, J. 2001. Relevance of microbial extracellular polymeric substances (EPSs)-Part I: Structural and ecological aspects. Water Sci. Tech. 43, 1-8.

Frankenberger Jr, W.T., Arshad, M. 2001. Bioremediation of selenium-contaminated sediments and water. Biofactors. 14, 241-254.

Frankenberger, W.T., Losi, M.E. 1995. Application of bioremediation in the cleanup of heavy elements and metalloids. In: Skipper, H. D. and Turco R.F. (Eds.), Bioremediation: Science and Applications, Soil Science Special Publication No. 43, Soil Science Society of America Inc., Madison, WI, USA. pp. 173-210.

Goldberg, S. 2010. Competitive adsorption of molybdenum in the presence of phosphorus or sulphur on Gibbsite. Soil Sci. 175, 105-110.

Grayston, S.J., Vaughan, D., Jones, D.L. 1997. Rhizosphere carbon flow in trees, in comparison with annual plants; the importance of root exudation and its impact on microbial activity and nutrient availability. Appl. Soil Ecol. 5, 29-56.

Hall, J.L. 2002. Cellular mechanisms for heavy metal detoxification and tolerance. J. Exp. Bot. 53, 1-11.

Harter, R.D.R., Naidu, R. 1995. Role of metal-organic complexation in metal sorption by soils. Adv. Agron. 55, 219-264.

Hawes, M.C., Gunawardena, U., Miyasaka, S., Zhao, X. 2000. The role of root border cells in plant defense. Trends Plant Sci. 5, 128-133.

Hinsinger, P. 2001. Bioavailability of soil inorganic P in the rhizosphere as affected by root-induced chemical changes: a review. Plant Soil. 237, 173-195.

Hinsinger, P., Plassard, C., Tang, C., Jaillard, B. 2003. Origins of root-mediated $\mathrm{pH}$ changes in the rhizosphere and their responses to environmental constraints: a review. Plant Soil. 248, 43-59.
Hong, C.O., Chung, D.Y., Lee, D.K., Kim, P.J. 2010. Comparison of phosphate materials for immobilizing cadmium in soil. Arch. Environ. Contam. Toxicol. 58, 268-274.

Hong, C.O., Lee, D.K., Chung, D.Y., Kim, P.J. 2007. Liming effects on cadmium stabilization in upland soil affected by gold mining activity. Arch. Environ. Contam. Toxicol. 52, 496-502.

Hsu, N.H., Wang, S.L., Lin, Y.C., Sheng, G.D., Lee, J.F. 2009. Reduction of $\mathrm{Cr}(\mathrm{VI})$ by crop-residuederived black carbon. Environ. Sci. Technol. 43, 8801-8806.

Jackson, B.P., Miller, W.P. 1999. Soluble arsenic and selenium species in fly ash/organic wasteamended soils using ion chromatographyInductively coupled plasma mass Spectrometry. Environ. Sci. Technol. 33, 270-275.

Javed, M.T., Stoltz, E., Lindberg S., Greger, M. 2013. Changes in $\mathrm{pH}$ and organic acids in mucilage of Eriphorum angustifolium roots after exposure to elevated concentrations of toxic elements. Environ. Sci. Pollut. Res. 20(3), 1876-1880.

Jones, D. L. 1998. Organic acids in the rhizospherea critical review. Plant Soil. 205, 25-44.

Khan, M.J., Jones, D.L. 2009. Effect of composts, lime and diammonium phosphate on the phytoavailability of heavy metals in copper mine tailing soil. Pedosphere. 19, 631-641.

Kim, J.G.D., Chusuei, J.B., Deng, C.C. 2002. Oxidation of chromium(III) to (VI) by manganese oxides. Soil Sci. Soc. Am. J. 66, 306-315.

Komárek, M., Ćadková, E., Chrastny, V., Bordas, F., Bollinger, J,-C. 2010. Contamination of vineyard soils with fungicides: a review of environmental and toxicological aspects. Environ. Intl. 36(1), 138-151. 
Koo, B.J., Chang, A.C., Crowley, D.E., Page, A.L. 2006. Characterization of organic acids recovered from rhizosphere of corn grown on biosolidstreated medium. Commun. Soil Sci. Plant Anal. $37,871-887$.

Kuiper, I., Lagendijk, E.L., Bloemberg, G.V., Lugtenberg, B.J.J. 2004. Rhizoremediation: a beneficial plant-microbe interaction. Mol. Plant Microbe Interact. 17, 6-15.

Lamb, D.T., Ming, H., Megharaj, M., Naidu, R. 2009. Heavy metal $(\mathrm{Cu}, \mathrm{Zn}, \mathrm{Cd}$ and $\mathrm{Pb})$ partitioning and bioaccessibility in uncontaminated and long-term contaminated soils. J. Hazard. Mater. 171, 11501158 .

Lambertsson, L., Nilsson, M. 2006. Organic material: the primary control on mercury methylation and ambient methyl mercury concentrations in estuarine sediments. Environ. Sci. Technol. 40, 1822-1829.

Lee, I.S., Kim, O.K., Chang, Y.Y., Bae, B., Kim, H.H., Baek, K.H. 2002. Heavy metal concentrations and enzyme activities in soil from a contaminated Korean shooting range. J. Biosci. Bioeng. 94, 406-411.

Lehr, C.R. 2003. Microbial methylation and volatilization of arsenic, $\mathrm{PhD}$ thesis, Department of chemistry. The University of British Columbia, Canada.

Li, H., Wang, J., Teng, Y., Wang, Z. 2006. Study on the mechanism of transport of heavy metals in soil in western suburb of Beijing. Chin. J. Geochem. 25, 173-177.

Li, R.Y., Ago, Y., Liu, W.J., Mitani, N., Feldmann, J., McGrath, S.P., Ma, J.F., Zhao, F.J. 2009. The rice aquaporin Lsil mediates uptake of methylated arsenic species. Plant Physiol. 150, 2071-2080.

Loseto, L.L., Siciliano, S.D., Lean, D.R.S. 2004. Methylmercury production in high Arctic wetlands. Environ. Toxicol. Chem. 23, 17-23.
Lu, P., Nuhfer, N.T., Kelly, S., Li, Q., Konishi, H., Elswick, E., Zhu, C. 2011. Lead coprecipitation with iron oxyhydroxide nano-particles. Geochim. Cosmochim. Ac. 75, 4547-4561.

Lynch, J.M., Whipps, J.M. 1990. Substrate flow in the rhizosphere. Plant Soil. 129, 1-10.

Ma, Y., Rajkumar, M., Freitas, H. 2009. Improvement of plant growth and nickel uptake by nickel resistant-plant-growth promoting bacteria. J. Hazard. Mater. 166, 1154-1164.

Mahimairaja, S., Bolan, N.S., Adriano, D., Robinson, B. 2005. Arsenic contamination and its risk management in complex environmental settings. Adv. Agron. 86, 1-82.

Mahler, R.J., Bingham, F.T., Page, A.L. 1978. Cadmium-enriched sewage sludge application to acid and calcareous soils: effect on yield and cadmium uptake by lettuce and chard. J. Environ. Qual. 7, 274-281.

Marschner, H. 1995. Functions of mineral nutrients: macronutrients. In: Marschner, H. (Ed.) Mineral nutrition of higher plants. Academic Press, NewYork. pp. 299-312.

McGowen, S.L., Basta, N.T., Brown, G.O. 2001. Use of diammonium phosphate to reduce heavy metal solubility and transport in smelter-contaminated soil. J. Environ. Qual. 30, 493-500.

McGrath, S.P., Zhao, F.J., Lombi, E. 2001 Plant and rhizosphere processes involved in phytoremediation of metal contaminated soils. Plant Soil. 232, 207-214.

McLaughlin, M.J., Tiller, K.G., Naidu, R., Stevens, D.P. 1996. Review: the behaviour and environmental impact of contaminants in fertilizers. Aust. J. Soil Res. 34, 1-54.

Meharg, A.A., Cairney, J.W.G. 2000. Extomycorrhizas - extending the capabilities of rhizosphere remediation. Soil Biol. Biochem. 32, 1475-1484. 
Mouta, E.R. Soares, M.R., Casagrande, J.C. 2008. Copper adsorption as a function of solution parameters of variable charge soils. J. Braz. Chem. Soc. 19, 996-1009.

Naidu, R., Bolan, N.S. 2008. Contaminant chemistry in soils: key concepts and bioavailability, In: Naidu, R. (Ed.), Chemical Bioavailability in Terrestrial Environment, Elsevier, Amsterdam, The Netherlands. pp. 9-38.

Naidu, R., Bolan, N.S., Kookana, R.S., Tiller, K.G. 1994. Ionic-strength and $\mathrm{pH}$ effects on the adsorption of cadmium and the surface charge of soils. Eur. J. Soil Sci. 45, 419-429.

Naidu, R., Kookana, R.S., Oliver, D.P., Rogers, S., McLaughlin, M.J. 1996. Contaminants and the Soil Environment in the Australasia-Pacific Region. Kluwer Academic Publishers, London.

Naidu, R., Kookana, R.S., Sumner, M.E., Harter, R.D., Tiller, K.G. 1997. Cadmium adsorption and transport in variable charge soils: A review. J. Environ. Qual. 26, 602-617.

Nancharaiah, Y.V., Dodge, C., Venugopalan, V.P., Narasimhan, S.V., Francis, A.J. 2010. Immobilization of $\mathrm{Cr}(\mathrm{VI})$ and its reduction to $\mathrm{Cr}$ (III) phosphate by granu-lar biofilms comprising a mixture of microbes. Appl. Environ. Microbiol. 76, 2433-2438.

Nelson, D.R., Mele, P.M. 2006. The impact of crop residue amendments and lime on microbial community structure and nitrogen-fixing bacteria in the wheat rhizosphere. Aust. J. Soil Res. 44, 319-329.

Newman, L.A., Reynolds, C.M. 2004. Phytodegradation of organic compounds. Curr. Opin. Biotechnol. 15, 225-230.
Nian, H., Yang, Z.M., Ahn, S.J., Cheng, Z.J., Matsumoto, H. 2002. A comparative study on the aluminium- and copper-induced organic acid exudation from wheat roots. Physiol. Plant. 116, 328-335.

Nocito, F.F, Lancilli, C., Dendena, B., Lucchini, G., Sacchi, G.A. 2011. Cadmium retention in rice roots is influenced by cadmium availability, chelation and translocation. Plant Cell Environ. 34, 994-1008.

Ok, Y. S., Oh, S. E., Ahmad, M., Hyun, S., Kim, K. R., Moon, D. H., Lee, S. S., Lim, K. J., Jeon, W.T. and Yang, J. E. 2010. Effects of natural and calcined oyster shells on $\mathrm{Cd}$ and $\mathrm{Pb}$ immobilization in contaminated soils. Environ. Earth Sci. 61, 13011308 .

Okeke, B. C. 2008. Bioremoval of hexavalent chromium from water by a salt tolerant bacterium, Exiguobacterium sp. GS1. J. Ind. Microbiol. Biotechnol. 35, 1571-1579.

Oliveira, A., Pampulha, M.E. 2006. Effects of longterm heavy metal contamination on soil microbial characteristics. J. Biosci. Bioeng. 102, 157-161.

Oremland, R.S., Herbel, M.J., Blum, J.S., Langley, S., Beveridge, T.J., Ajayan, P.M., Sutto, T., Ellis, A.V., Curran, S. 2004. Structural and spectral features of selenium nanospheres produced by Se-respiring bacteria. Appl. Environ. Microbiol. 70, 52-60.

Park, D., Yun, Y.S.. Park, J.M. 2004. Reduction of hexavalent chromium with the brown seaweed Ecklonia biomass. Environ. Sci. Technol. 38, 4860-4864.

Park, J.H., Lamb, D., Paneerselvam, P., Choppala, G.K., Bolan, N.S., Chung, J-W. 2011. Role of organic amendments on enhanced bioremediation of heavy metal(loid) contaminated soils. J. Hazard. Mater. 185, 549-574. 
Patten, C.L., Glick, B.R. 2002. Role of Pseudomonas putida indoleacetic acid in development of the host plant root system. Appl. Environ. Microbiol. $68,3795-3801$.

Pearse, S.J., Veneklaas, E.J., Cawthray, G., Bolland, M.D.A., Lambers, H. 2006. Triticum aestivum shows a greater biomass response to a supply of aluminium phosphate than Lupinus albus, despite releasing fewer carboxylates into the rhizosphere. New Phytol. 169, 515-524.

Pearse, S.J., Veneklaas, E.J., Cawthray, G., Bolland, M.D.A., Lambers, H. 2007. Carboxylate composition of root exudates does not relate consistently to a crop species' ability to use phosphorus from aluminium, iron or calcium phosphate sources. New Phytol. 173, 181-190.

Penrose, D.M., Moffatt, B.A., Glick, B.R. 2001. Determination of 1-aminocycopropane-1carboxylic acid (ACC) to assess the effects of ACC deaminase-containing bacteria on roots of canola seedlings. Can. J. Microbiol. 47, 77-80.

Peryea, F.J. 1991. Phosphate-induced release of arsenic from soils contaminated with lead arsenate. Soil Sci. Soc. Amer. J. 55, 1301-1306.

Pietrobelli, J.M.T.A., Modenes, A.N., Fagundes-Klen, M.R., Espinoza-Quinones, F. R. 2009. Cadmium, copper and zinc biosorption study by non-living Egeria densa biomass. Water Air Soil Pollut. 202, 385-392.

Pii, Y., Mimmo, T., Tomasi, N., Terzano, R., Cesco, S., Crecchio, C. 2015. Microbial interactions in the rhizosphere: beneficial influences of plant growth-promoting rhizobacteria on nutrient acquisition process. A review. Biol. Fert. Soils 51(4), 403-415.

Rajkumar, M., Nagendran, R., Lee, K.J., Lee, W.H., Kim, S.Z. 2006. Influence of plant growth promoting bacteria and $\mathrm{Cr}^{6+}$ on the growth of Indian mustard. Chemosphere. 62, 741-748.
Rengel, Z. 1997. Root exudation and microflora populations in rhizosphere of crop genotypes differing in tolerance to micronutrient deficiency. Plant Soil. 196, 255-260.

Rengel, Z. 2002. Genetic control of root exudation. Plant Soil. 245, 59-70.

Robinson, B., Greven, M., Green, S., Sivakumaran, S., Davidson, P., Clothier, B. 2006. Leaching of copper, chromium and arsenic from treated vineyard posts in Marlborough, New Zealand. Sci. Total Environ. 364, 113-123.

Rodríguez, R., Tessier, E., Amouroux, D., Guyoneaud, R., Duran, R., Caumette, P., Donard, O. 2004. Mercury methylation/demethylation and volatilization pathways in estuarine sediment slurries using species-specific enriched stable isotopes. Mar. Chem. 90, 107-123.

Ross, S.M. 1994. Retention, transformation and mobility of toxic metals in soils, In: S.M. Ross (Ed.), Toxic Metals in Soil-Plant Systems. Wiley, New York. pp. 63-152.

Rumberg, C.B., Engel, R.E., Meggit, W.F. 1960. Effect of phosphorus concentration on the absorption of arsenate by oats from nutrient solution. Agron. J. 52, 452-453.

Ryan, P.R., DiTomaso, J.M.. Kochian, L.V. 1993. Aluminum toxicity in roots: an investigation of spatial sensitivity and the role of the root cap. J. Exp. Bot. 44, 437-446.

Santibanez, C., Verdugo, C., Ginocchio, R. 2008. Phytostabilization of copper mine tailings with biosolids: Implications for metal uptake and productivity of Lolium perenne. Sci. Total Environ. 395, 1-10.

Satpute, S.K., Banat, I.M., Dhakephalkar, P.K., Banpurkar, A.G., Chopade, B.A. 2010. Biosurfactants, bioemulsifiers and exopolysaccharides from marine microorganisms. Biotechnol. Adv. 28, 436-450. 
Sghayar, S., Ferri, A., Lancilli, C., Lucchini, G., Abruzzese, A., Porrini, M., Ghnaya, T., Nocito, F.F., Abdelly, C., Sacchi, G.A. 2015. Analysis of cadmium translocation, partitioning and tolerance in six barley (Hordeum vulgare L.) cultivars as a function of thiol metabolism. Biol. Fert. Soils. 51(3), 311-320.

Sheng, X., Xia, J. 2006. Improvement of rape (Brassica napus) plant growth and cadmium uptake by cadmium-resistant bacteria. Chemosphere. 64, 1036-1042.

Shuman, L.M. 1985. Effect of ionic strength and anions on zinc adsorption by two soils. Soil Sci. Soc. Am. J. 50, 1438-1442.

Siciliano, S.D., Germida, J.J. 1998. Mechanisms of phytoremediation: biochemical and ecological interactions between plants and bacteria. Environ. Rev. 6, 65-79.

Singh, B.K., Munro, S., Potts, J.M., Millard, P. 2007. Influence of grass species and soil type on rhizosphere microbial community structure in grassland soils. Appl. Soil Ecol. 36, 147-155.

Sparks, D.L. 2003. Environmental Soil Chemistry. Second ed., Academic Press, San Diego.

Sposito, G. 1984. The Surface Chemistry of Soils. Oxford University Press, New York.

Stahl, R.S.. James, B.R. 1991. Zinc sorption by B horizon soils as a function of $\mathrm{pH}$. Soil Sci. Soc. of Am. J. 55, 1592-1597.

Suh, J.H., Yun, J.W., Kim, D.S. 1999. Effect of extracellular polymeric substances (EPS) on $\mathrm{Pb}^{2+}$ accumulation by Aureobasidium pollulans, Bioporcess Biosyst. Eng. 21 1-4.

Tang, C., Raphael, C., Rengel, Z., Bowden, J.W. 2000. Understanding subsoil acidification: effect of nitrogen transformation and nitrate leaching. Aust. J. Soil Res. 38, 837-850.
Tang, J., Baldocchi, D.D., Xu, L. 2005. Tree photosynthesis modulates soil respiration on a diurnal time scale. Global Change Biol. 11(8), 1298-1304.

Tao, S., Liu, W.X., Chen, Y.J., Xu, F.L., Dawson, R.W., Li, B.G., Cao, J. Wang, X. J., Hu, J.Y., Fang, J.Y. 2004. Evaluation of factors influencing root-induced changes of copper fractionation in rhizosphere of a calcareous soil. Environ. Pollut. $129,5-12$.

Tyler, G. 1978. Leaching rates of heavy metal ions in forest soil. Water Air Soil Pollut. 9, 137-148.

Uren, N.C. 2007. Types, Amounts, and possible functions of compounds released into the rhizosphere by soil-grown plants. In: Pinton, R., Varanini, Z. and Nannipieri, P. (Eds.). The Rhizosphere: Biochemistry and Organic Substances at the Soil-plant Interface. Taylor and Francis Group, Boca Raton, FL, pp. 1-21.

Violante, A., Cozzolino, V., Perelomov, L., Caporale, A., Pigna, M. 2010. Mobility and bioavailability of heavy metals and metalloids in soil environments. J. Soil Sci. Plant Nutr. 10, 268-292.

Violante, A., del Gaudio, S., Pigna, M., Ricciardella, M., Banerjee, D. 2007. Precipitation of arsenate with metal oxides. 2. Nature, mineralogy, and reactivity of iron(III) precipitates. Environ. Sci. Technol. 41, 8275-8280.

Volesky, B. 1990. Removal and recovery of heavy metals by biosorption. In: Biosorption of Heavy Metals; Volesky, B. (Ed.), CRC Press: Boca Raton, Florida. pp. 7-44.

Vyslouzilova, M., Puschenreiter, M. Wieshammer, G., Wenzel, W.W. 2006. Rhizosphere characteristics, heavy metal accumulation and growth performance of two willow (Salix x rubens) clones. Plant Soil Environ. 52, 353-361. 
Walker, T.S., Bais, H.P., Grotewold, E., Vivanco, J.M. 2003. Root exudation and rhizosphere biology. Plant Physiol. 132, 44-51.

Weng, L., Lexmond, T.M., Wolthoorn, A., Temminghoff, E.J.M., Van Riemsdijk, W. H. 2003. Phytotoxicity and bioavailability of nickel: chemical speciation and bioaccumulation. Environ. Toxicol. Chem. 22, 2180-2187.

Weng, L., Lexmond, T.M. Wolthoorn, A. Temminghoff, E.J.M., Van Riemsdijk, W. H. 2004. Understanding the effects of soil characteristics on phytotoxicity and bioavailability of nickel using speciation models. Environ. Sci. Technol. 38, 156-162.

Wenzel, W.W. 2009. Rhizosphere processes and management in plant-assisted bioremediation (phytoremediation) of soils. Plant Soil. 321, 385408.

Wheeler, J.I., Irving, H.R. 2010. Evolutionary advantages of secreted peptide signalling molecules in plant. Funct. Plant Biol. 37, 382-394.

Wiatrowski, H.A., Ward, P.M., Barkay, T. 2006. Novel reduction of mercury (II) by mercury-sensitive dissimilatory metal reducing bacteria. Environ. Sci. Technol. 40, 6690-6696.

Wu, C.-H., Lo, S.-L., Lin, C.-F., Kuo, C.-Y. 2001. Modeling competitive adsorption of molybdate. sulfate, and selcnatc oil by the triple-layer model. J. Colloid Interface Sci. 233, 259-264.

Yang, R., Tang, J., Chen, X., Hu, S. 2007. Effects of coexisting plant species on soil microbes and soil enzymes in metal lead contaminated soils. Appl. Soil Ecol. 37, 240-246.
Yang, S., Xing, S., Liu, C., Du, Z., Wang, H. Xu, Y. 2010. Effects of root pruning on the vegetative growth and fruit quality of Zhanhuadongzao trees. Hort. Sci. 1, 14-21.

Yin, X.X., Chen, J., Qin, J., Sun, G.X., Rosen, B.P., Zhu, Y.G. 2011. Biotransformation and volatilization of arsenic by three photosynthetic cyanobacteria. Plant Physiol. 156, 1631-1638.

Zenteno, M.D.C., de Freitas, R.C.A., Fernandes, R.B.A., Fontes, M.P.F., Jordão, C.P. 2013. Sorption of cadmium in some soil amendments for in situ recovery of contaminated soils. Water Air Soil Pollut. 224, 1418-1426.

Zhang, H., Sun, Y., Xie, X., Kim, M.S., Dowd, S.E., Paré, P.W. 2009. A soil bacterium regulates plant acquisition of iron via deficiency-inducible mechanisms. Plant J. 58, 568-577.

Zhang, M.Y., Bourbouloux, A., Cagnac, O., Shrikanth, C.V., Rentsch, D., Bachhawat, A.K., Delrot, S. 2004. A novel family of transporters mediating the transport of glutathione derivatives in plants. Plant Physiol. 134, 482-491.

Zhang, Y.Q., Frankenberger, W.T. 1999. Effects of soil moisture, depth, and organic amendments on selenium volatilization. J. Environ. Qual. 28, 1321-1326.

Zhao, F.J., Hamon, R.E., McLaughlin, M.J. 2001. Root exudates of the hyperaccumulator Thlaspi caerulescens do not enhance metal mobilization. New Phytol. 151, 613-620. 